\title{
Fomitopsis betulina (formerly Piptoporus betulinus): the Iceman's polypore fungus with modern biotechnological potential
}

\author{
Małgorzata Pleszczyńska $^{1} \cdot$ Marta K. Lemieszek $^{2} \cdot$ Marek Siwulski $^{4}$. \\ Adrian Wiater $^{1} \cdot$ Wojciech Rzeski $^{2,3} \cdot$ Janusz Szczodrak $^{1}$
}

Received: 31 January 2017 / Accepted: 15 March 2017 / Published online: 4 April 2017

(C) The Author(s) 2017. This article is an open access publication

\begin{abstract}
Higher Basidiomycota have been used in natural medicine throughout the world for centuries. One of such fungi is Fomitopsis betulina (formerly Piptoporus betuli$n u s$ ), which causes brown rot of birch wood. Annual white to brownish fruiting bodies of the species can be found on trees in the northern hemisphere but $F$. betulina can also be cultured as a mycelium and fruiting body. The fungus has a long tradition of being applied in folk medicine as an antimicrobial, anticancer, and anti-inflammatory agent. Probably due to the curative properties, pieces of its fruiting body were carried by Ötzi the Iceman. Modern research confirms the health-promoting benefits of $F$. betulina. Pharmacological studies have provided evidence supporting the antibacterial, anti-parasitic, antiviral, anti-inflammatory, anticancer, neuroprotective, and immunomodulating activities of $F$. betulina preparations. Biologically active compounds such as triterpenoids have been isolated. The mushroom is also a reservoir of valuable enzymes and other substances such as cell wall $(1 \rightarrow 3)$ - $\alpha$-D-glucan which can be used for induction of microbial enzymes degrading cariogenic dental biofilm. In conclusion, $F$. betulina can be considered as
\end{abstract}

Małgorzata Pleszczyńska

m.pleszczynska@poczta.umcs.lublin.pl

1 Department of Industrial Microbiology, Maria CurieSkłodowska University, Akademicka 19, 20-033 Lublin, Poland

2 Department of Medical Biology, Institute of Rural Health, Jaczewskiego 2, 20-095 Lublin, Poland

3 Department of Virology and Immunology, Maria CurieSkłodowska University, Akademicka 19, 20-033 Lublin, Poland

4 Department of Vegetable Crops, Poznań University of Life Sciences, Dąbrowskiego 159, 60-594 Poznań, Poland a promising source for the development of new products for healthcare and other biotechnological uses.

Keywords Biological activity $\cdot$ Cultivation - Fomitopsis betulina $\cdot$ Phytochemistry $\cdot$ Piptoporus betulinus

\section{Introduction}

In 1991, a mummified body was discovered in the Val Senales glacier in Italy. The man (named Ötzi the Iceman), who lived 5300 years ago, carried two fragments of a fruiting body of Fomitopsis betulina (formerly Piptoporus betulinus). Some scientists believe that Ötzi might have used the fungus for medical purposes (Capasso 1998) and, although the idea arouses some controversy (Pöder 2005), the long tradition of the use of $F$. betulina in folk medicine is a fact (Reshetnikov et al. 2001; Wasser 2010). Infusion from $F$. betulina fruiting bodies was popular, especially in Russia, Baltic countries, Hungary, Romania for its nutritional and calming properties. Fungal tea was used against various cancer types, as an immunoenhancing, anti-parasitic agent, and a remedy for gastrointestinal disorders (Grienke et al. 2014; Lucas 1960; Peintner and Pöder 2000; Semerdžieva and Veselský 1986; Shamtsyan et al. 2004). Antiseptic and anti-bleeding dressings made from fresh $F$. betulina fruiting body were applied to wounds and the powder obtained from dried ones was used as a painkiller (Grienke et al. 2014; Papp et al. 2015; Rutalek 2002).

In the present paper, we have shown the current knowledge of the fungus $F$. betulina, including its lifestyle, chemical composition, and potential in biotechnology. 


\section{Taxonomy and characteristics}

Piptoporus betulinus (Bull.) P. Karst. (known as birch polypore, birch bracket, or razor strop) is a common Basidiomycota brown rot macrofungus growing on decaying birch wood. Homobasidiomycetes were divided into eight clades. The family Polyporaceae with the genus Piptoporus was classified to the polyporoid clade, and then the antrodia clade-the Fomitopsis-Daedalea-Piptoporus group comprising brown rot fungi was identified within this clade (Hibbett and Donoghue 2001; Hibbett and Thorn 2001). Further studies of the phylogenetic relationships among members of the antrodia clade revealed polyphyly of the Fomitopsis genus and suggested that P. betulinus was phylogenetically closer to Fomitopsis than to Piptoporus (Kim et al. 2005; Ortiz-Santana et al. 2013). Recently, P. betulinus (Bull.) P. Karst. has been transferred to Fomitopsis (Han et al. 2016) and, according to Index Fungorum (2016), is classified in the genus Fomitopsis, family Fomitopsidaceae, order Polyporales, class Agaricomycetes, division Basidiomycota, kingdom Fungi, with the current name Fomitopsis betulina (Bull.) B.K. Cui, M.L. Han and Y.C. Dai, comb.nov. (MycoBank no.: MB 812646).

Fomitopsis betulina is characterized by annual, sessile to effused-reflexed, tough to woody hard basidiocarps, white to tan or pinkish-colored pore surface with mostly small and regular pores. Fruiting bodies grow singly or in small groups, are covered with a laccate, glabrous crust, never zonate, young cream to white, later ochraceous-brown to greyish brown (Fig. 1a). The mycelium of $F$. betulina developing on agar media is white, relatively homogeneous, downy-felt, with regular colony edges (Fig. 1b). The hyphae develop radially. The hyphal system is mostly dimitic. The clamped generative hyphae, $1.5-3.5 \mu \mathrm{m}$ in diameter, are branched and hyaline whereas the skeletal hyphae with the diameter of 3-4 $\mu \mathrm{m}$, are less branched and have thicker walls. No primordia or fruiting bodies of this species were found in vitro (Petre and Tanase 2013). Basidiospores are smooth, hyaline, thin-walled, and cylindrical (Han and Cui 2015; Han et al. 2016; Kim et al. 2005; Schwarze 1993).

The birch polypore grows mainly as a saprophyte on dead trees and occasionally as a parasite of living trees. It occurs in northern temperate forests and parks in Europe, North America, and Asia. The host range of the fungus is restricted exclusively to birch species, e.g. Betula pendula Roth., B. pubescens Ehrh., B. papyrifera Marsh., and B. obscura Kotula (Schwarze 1993; Žižka et al. 2010).

\section{Wood decay}

Wood rotting fungi are traditionally divided into white and brown rot species based on the structure and composition of residual wood. Brown rot fungi extensively degrade the carbohydrate fraction of lignocellulose but, in contrast to white rot fungi, leave lignin, although in a modified form. In these fungi, chemical depolymerization of cellulose, which precedes and supports its enzymatic degradation, is very important. They lack ligninolytic peroxidases and usually some other enzymes such as processive cellobiohydrolases used for degradation of crystalline cellulose, but contain $\mathrm{H}_{2} \mathrm{O}_{2}$-generating oxidases and $\mathrm{Fe}^{3+}$ - and quinone-reducing enzymes used for non-enzymatic depolymerization of polysaccharides (Arantes and Goodell 2014; Baldrian and Valášková 2008; Hori et al. 2013). Modern phylogenetic evidence suggest, however, that there is no sharp distinction between the two groups of fungi (Hori et al. 2013; Riley et al. 2014).

Fomitopsis betulina is one of the most common brown rot species but its wood-decaying mechanism has been tested only fragmentarily (Meng et al. 2012) and is still poorly
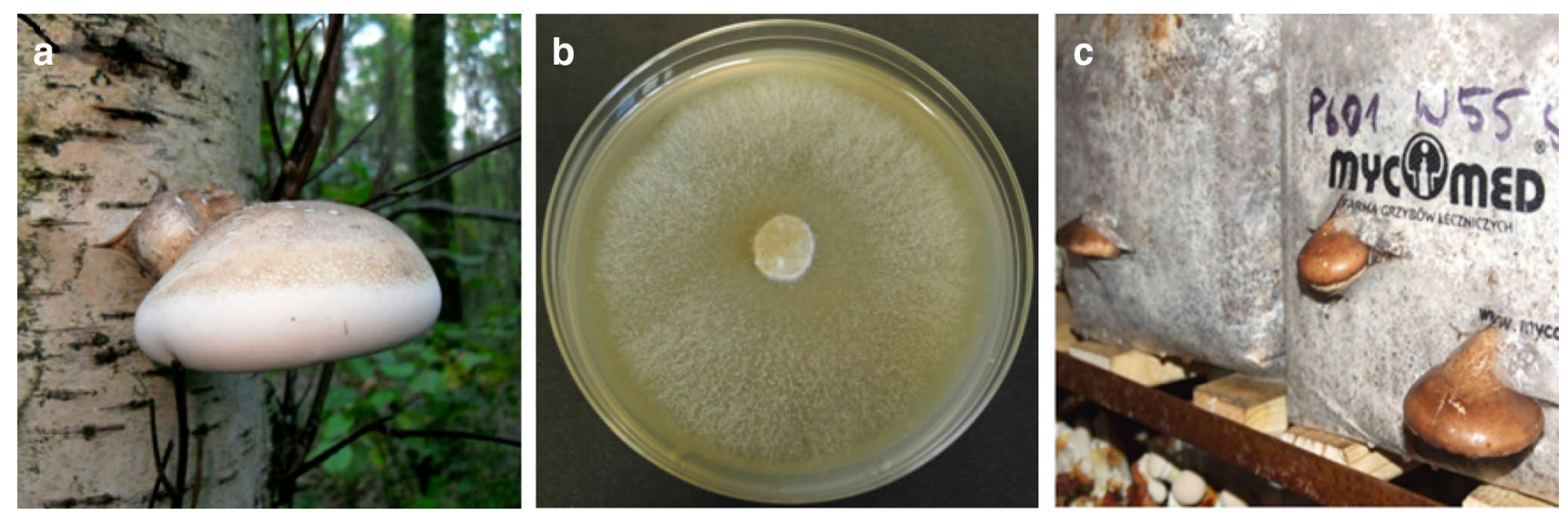

Fig. 1 Fomitopsis betulina. a Basidiocarp of the wild fungus. b Mycelium on an agar plate. c Mature fruiting body cultured on birch sawdust in artificial conditions. (photographed by M. Siwulski) 
understood. As other fungi of this type, it degrades wood to yield brown, cubical cracks easily broken down. Many factors, including microflora or compounds present in wood, contribute to this complex process (Przybył and ŻłobińskaPodejma 2000; Song et al. 2016; Zarzyński 2009). Shang et al. (2013) showed that wood samples decayed by F. betulina lost $57 \%$ of dry weight (dw) and $74 \%$ of holocellulose after 30 days, whereas the fungus growing on wheat straw causes $65 \%$ loss of dw within 98 days of culture (Valášková and Baldrian 2006a). A set of enzymes of $F$. betulina involved in the degradation of lignocellulose was characterized in detail by Valášková and Baldrian (2006a, b). The fungus growing on straw produced enzymes with wide substrate specificities: $(1 \rightarrow 4)$ - $\beta$-endoglucanase, $\beta$-glucosidase, $(1 \rightarrow 4)$ - $\beta$-endoxylanase, $\quad(1 \rightarrow 4)-\beta$-endomannanase, $(1 \rightarrow 4)-\beta$-xylosidase, and $(1 \rightarrow 4)-\beta$-mannosidase. The activities of ligninolytic enzymes and cellobiose dehydrogenase for oxidoreductive cleavage of cellulose were not detected. Similar results were obtained in liquid cultures by Větrovský et al. (2013). When F. betulina grew in nature, $\beta$-glucosidase and $\beta$-mannosidase activity was associated with the fruiting bodies while endopolysaccharidases were detected in colonized wood (Valášková and Baldrian 2006a).

\section{Cultivation}

Carpophores of $F$. betulina from natural habitats or mycelium and culture liquid from submerged cultures were used as raw material to obtain extracts and bioactive substances with medicinal properties (Table 1) (Lomberh et al. 2002). Studies concerning the mycelium growth rate in the presence of various substances (metals, dyes) were conducted mainly on agar media or in liquid cultures (Baldrian and Gabriel 2002; Dresch et al. 2015; Hartikainen et al. 2016). The yield of $F$. betulina mycelium was established in liquid cultures with addition of some agricultural wastes in the studies of Krupodorova and Barshteyn (2015). The enzymatic activity of $F$. betulina was studied in laboratory conditions on agar media (Krupodorova et al. 2014), in liquid cultures (Větrovský et al. 2013), on wheat straw (Valášková and Baldrian 2006a, b), and on Betula sp. wood samples (Reh et al. 1986; Shang et al. 2013).

There are limited data on small- or large-scale cultivation of this species in which carpophores could be obtained in controlled conditions. The first such report referring to outdoor log cultivation of $F$. betulina on Betula davurica Pallas originated from Korea (Ka et al. 2008). Logs with a diameter of 8-18 cm and length of $107-135 \mathrm{~cm}$ were inoculated and then cultured in natural conditions. The yield obtained was in the range from 212 to $1298 \mathrm{~g}$ fresh weight (1-2 mushrooms per log). Development of fruiting bodies took an average of 18 months. The ratio of log yield was estimated at $2.8-6.1 \%$. The only report on indoor production of $F$. betulina fruiting bodies was given by Pleszczyńska et al. (2016). In the study, four strains of $F$. betulina isolated from natural habitats were applied. Their mycelia were inoculated into birch sawdust supplemented with organic additives. Mature fruiting bodies weighing from 50 to $120 \mathrm{~g}$ were obtained from only one strain, after 3-4 months of the cultivation in artificial conditions (Fig. 1c). The biological efficiency ranged from 12 to $16 \%$. It was shown that extracts isolated from cultivated and naturally grown $F$. betulina fruiting bodies had comparable biological activity (Table 1).

\section{Biotechnological uses}

\section{Phytochemistry and pharmacological activity}

Comprehensive analyses of the chemical composition of the $F$. betulina fruiting body carried out under different conditions (Grishin et al. 2016; Hybelbauerová et al. 2008; Reis et al. 2011) revealed the presence of 17 fatty acids, in it 22\% saturated and $78 \%$ unsaturated (mainly oleic and linoleic acid); sugars (D-arabinitol, D-mannitol and $\alpha, \alpha$ trehalose); biomolecules with antioxidant properties (tocopherols $-0.578 \mathrm{mg} / 100 \mathrm{~g} \mathrm{dw}$, mainly $\beta$ and $\gamma$; ascorbic acid$87.5 \mathrm{mg} / 100 \mathrm{~g} \mathrm{dw} ; \beta$-carotene and lycopene). Among other identified compounds were betulinic acid, betulin, lupeol, fomefficinic acid, ergosterol peroxide, and 9,11-dehydroergosterol peroxide (Alresly et al. 2016; Jasicka-Misiak et al. 2010). Total content of phenolics was determined on 14 or $35 \mathrm{mg} \mathrm{GAE} / \mathrm{g} \mathrm{dw}$ whereas phenolic acids were not detected (Reis et al. 2011; Sułkowska-Ziaja et al. 2012). Product of hydrodistillation of $F$. betulina fruiting bodies contained numerous volatile mono- and sesquiterpenes. Several compounds found, (+)- $\alpha$-barbatene, $(-)-\beta$-barbatene, daucene and isobazzanene, have not been previously reported from other mushrooms. Alcohols, 3-octanol and 1-octen-3-ol, were the main flavour constituents of the fungus (Rapior et al. 1996; Rösecke et al. 2000).

Although some authors considered young specimens of $F$. betulina edible (Wasson 1969), the fungus value is not the result of nutritional but therapeutic properties. The overview of the available literature concerning medical potential of birch polypore was presented in Table 1. Referring to the folk uses of the birch polypore, most of the presented research was based on crude extracts, which often have greater bioactivity than isolated constituents at an equivalent dose. This phenomenon is explained by mostly synergistic interactions between compounds present in mixtures. Furthermore, extracts often contain substances that inhibit multi-drug 


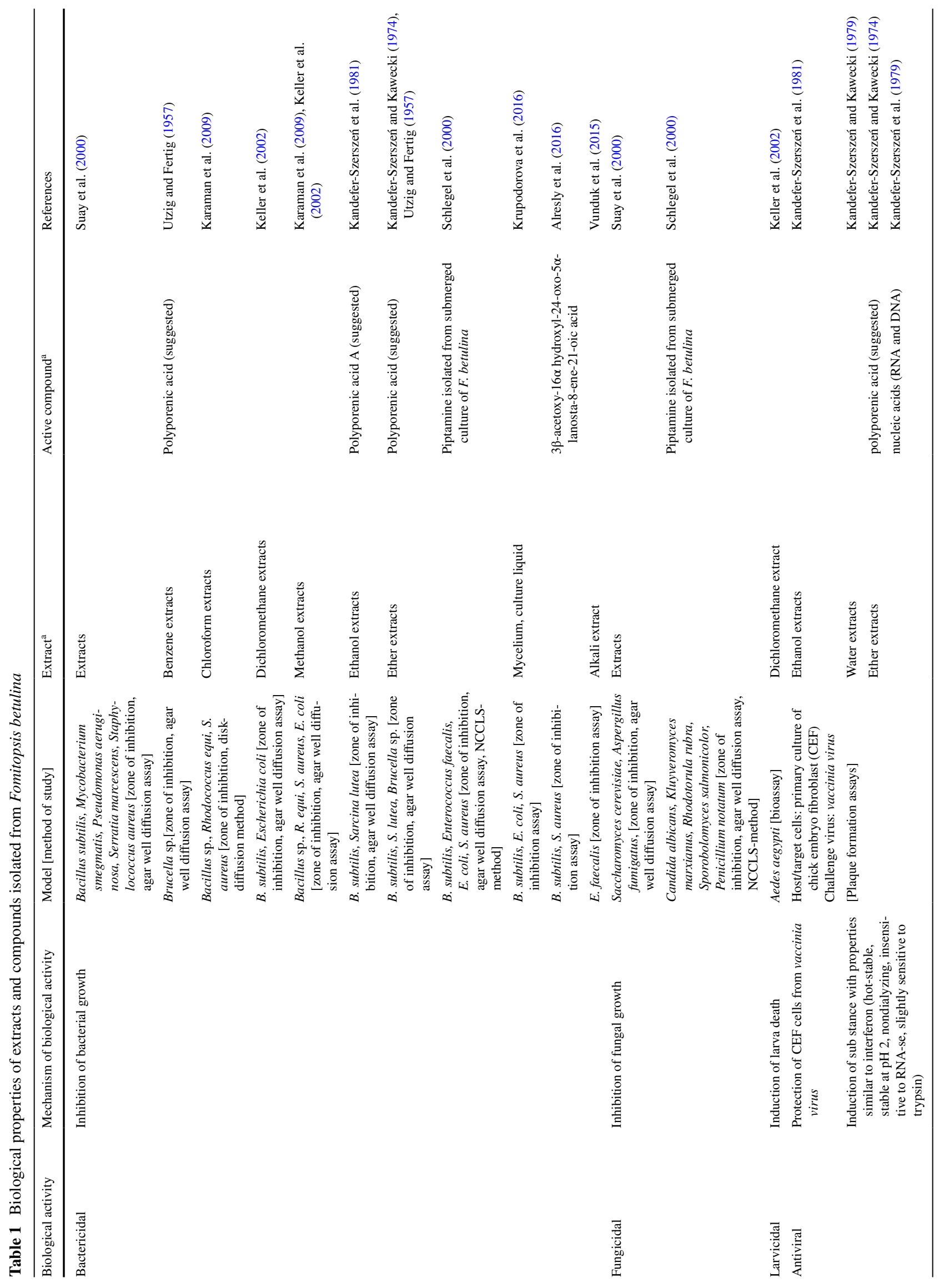




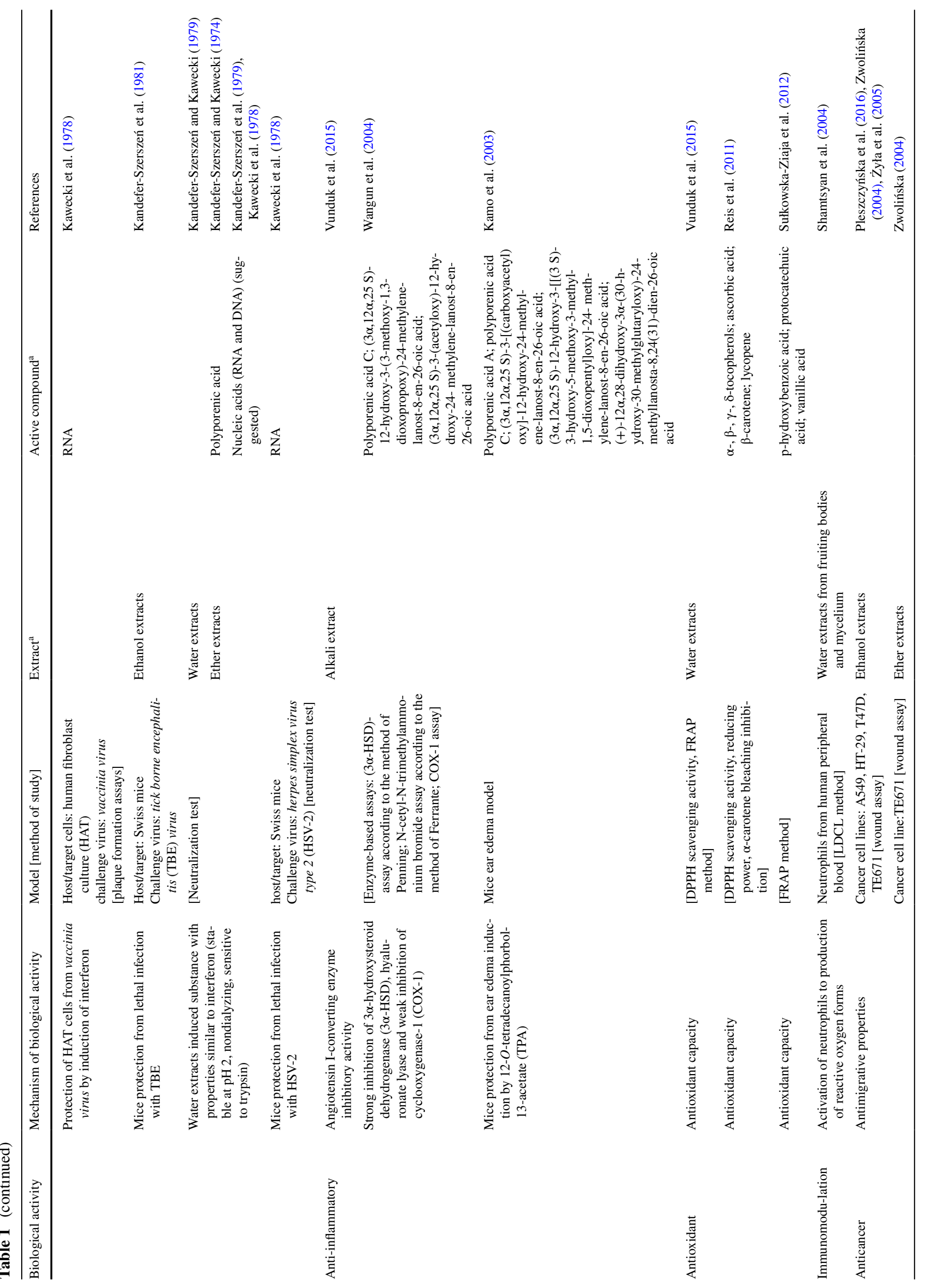




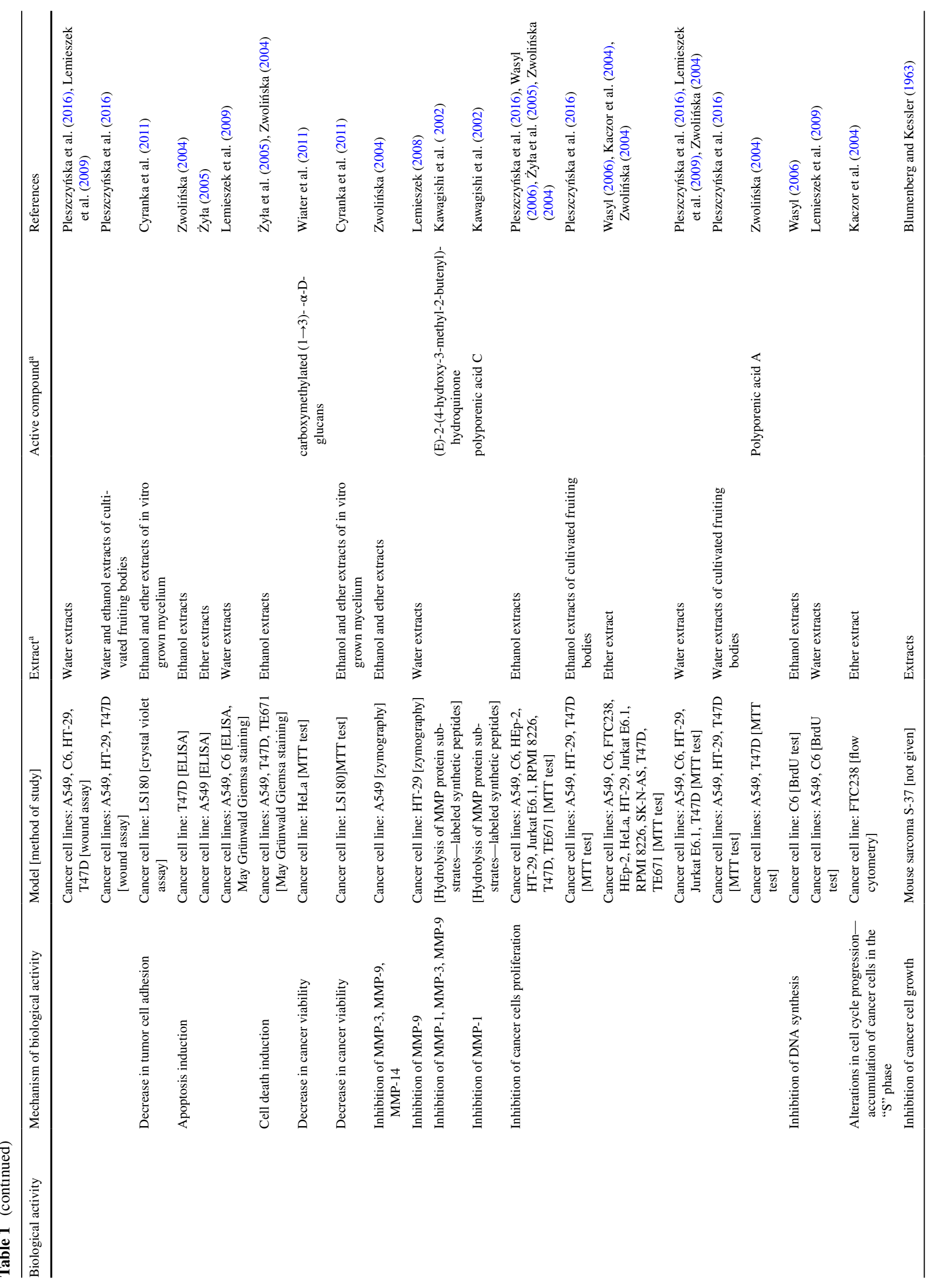




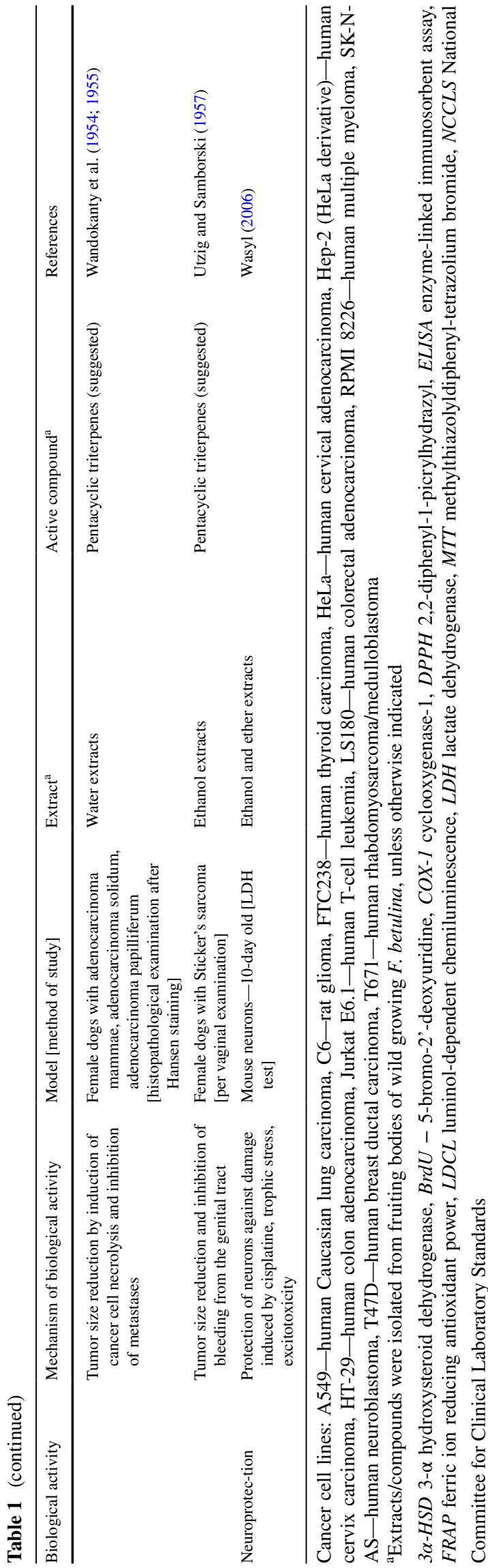

resistance and therefore further increase the effectiveness of the active substances. Particularly noteworthy among the wide variety of biological activities of $F$. betulina extract, are properties proved in in vivo studies, e.g. the efficacy of water and ethanol extracts in treatment of the genital tract in dogs (Utzig and Samborski 1957; Wandokanty et al. 1954, 1955) or mice protection from lethal infection with the TBE virus by water, ethanol, and ether extracts (Kandefer-Szerszeń et al. 1981; Kandefer-Szerszeń and Kawecki 1974, 1979). The broad spectrum of antiviral and antimicrobial activity of $F$. betulina extracts proved by a number of research teams in different models based on different techniques deserves special attention as well (see references cited in Table 1). Recently, Stamets $(2011,2014)$ has invented formulations prepared from different medicinal mushrooms including $F$. betulina, which are useful in preventing and treating viral and bacterial diseases, i.e. herpes, influenza, SARS, hepatitis, tuberculosis, and infections with $E$. coli and $S$. aureus .

Some pure compounds corresponding to the bioactivity of the birch polypore were also identified (Fig. 2). They belong to several chemical classes but the greatest attention was paid to small molecular weight secondary metabolites, especially triterpenoids. Kamo et al. (2003) isolated several triterpenoid carboxylic acids with a lanostane skeleton, e.g. polyporenic acids and their derivatives (Table 1). In in vivo tests, the substances suppressed TPA-induced mouse ear inflammation up to $49-86 \%$ at the dose of $0.4 \mu \mathrm{M} /$ ear. Alresly et al. (2016) purified one previously unknown (identified as $3 \beta$-acetoxy-16 $\alpha$ hydroxyl-24-oxo-5 $\alpha$-lanosta-8-ene-21oic acid) and ten known triterpenes from ethyl acetate extract of fruiting bodies of the fungus. The new compound showed anti-gram-positive bacteria activity. The medicinal activity of some triterpenoids tested was examined more accurately. It was shown that polyporenic acid $\mathrm{C}$, just like another compound isolated from $F$. betulina, i.e. (E)-2-(4-hydroxy-3methyl-2-butenyl)-hydroquinone, had inhibitory activity against some matrix metalloproteinases (MMP), with $\mathrm{IC}_{50}$ values (concentration causing inhibition by $50 \%$ compared to control) in the range from 23 to $128 \mu \mathrm{M}$ (Kawagishi et al. 2002). Polyporenic acid C and three other $F$. betulina triterpenoids (Table 1) showed anti-inflammatory and antibacterial activity by strong inhibition of $3 \alpha$-hydroxysteroid dehydrogenase and bacterial hyaluronate lyase activity, respectively (Wangun et al. 2004).

In their search for fungal antimicrobial substances, Schlegel et al. (2000) isolated another valuable compound-piptamine, N-benzyl-N-methylpentadecan1-amine from submerged culture of $F$. betulina Lu 9-1. It showed activity against gram-positive bacteria (MIC, 
<smiles>C=C(CCC(C)[C@H]1CC[C@H]2C3=C(CC[C@H]4[C@@H](C)C(O)CC[C@]34C)[C@@]21C)CC(=O)O</smiles>

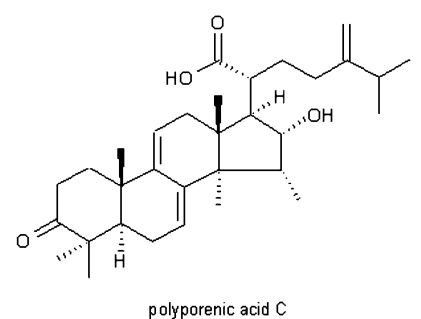

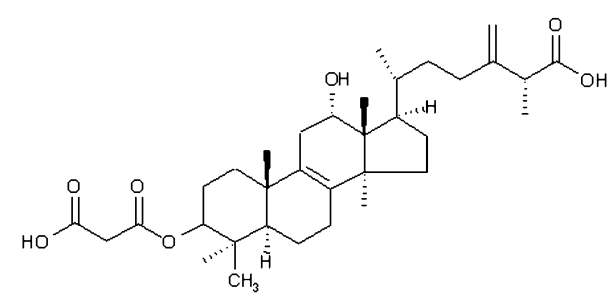

(3a,12a 25S)-3-[(carboxyacety))oxy\}-12-hydroxy-24-methylene-lanost-8-en-26-oic acid

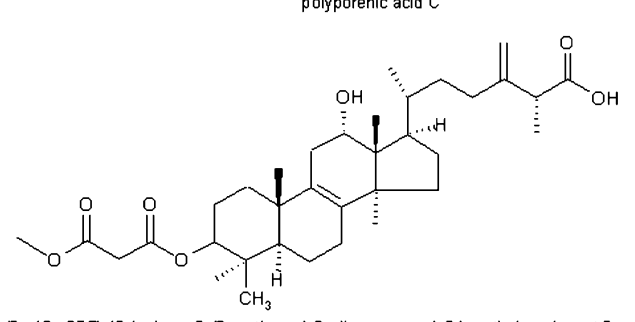

(3a,12 «25S)-12-hydroxy-3-(3-metho xy-1,3- dioxopropoxy)-24-meth ylene-lanost-8-en-26-oic acid

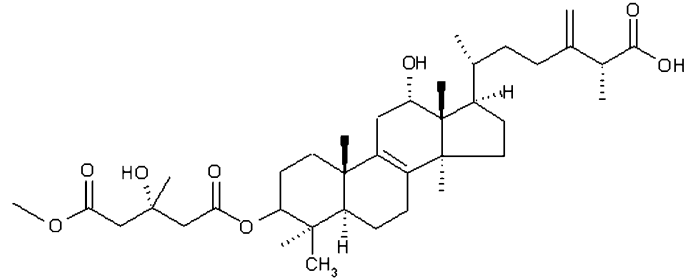

(3a, 12a 25S)-12-hydroxy-3-[[3S)-3-hydroxy-5- methoxy-3-methyl-1,5-dioxopenty]]0xy]-24methylene-lanost-8-en-26-oic acid

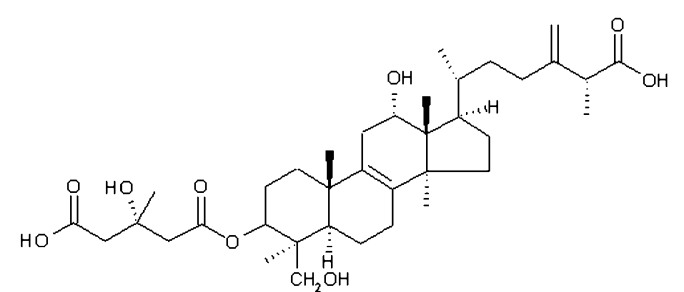

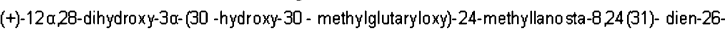
oic acid

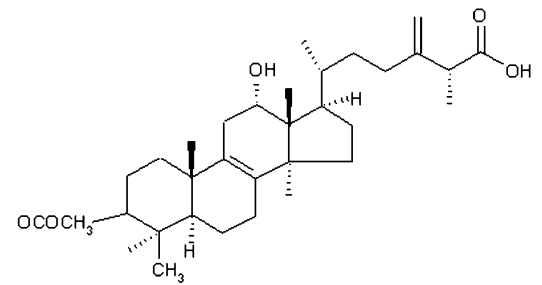

(3a,12a,25S)-3-(acetyloxy)-12-hydroxy-24- methylene-lanost-8-en-26-oic acid<smiles>O=C(O)c1ccc(O)c(O)c1</smiles><smiles>COc1cc(C(=O)O)ccc1O</smiles>

vanillic acid<smiles>Cc1c(C)c2c(c(C)c1O)CC[C@@](C)(CCC[C@H](C)CCC[C@H](C)CCCC(C)C)O2</smiles>

a-tocopherol

HO<smiles>Cc1c(O)cc2c(c1C)O[C@](C)(CCC[C@H](C)CCC[C@H](C)CCCC(C)C)CC2</smiles><smiles>CCCCCCCCCCCCCCCN(C)Cc1ccccc1</smiles>

piptamine<smiles>C/C(=C\Cc1cc(O)ccc1O)CO</smiles><smiles>O=C1O[C@H]([C@@H](O)CO)C(O)=C1O</smiles>

(E)-2-(4-hydroxy-3-methyl-2-butenyl)-hydroquinone

ascorbic acid

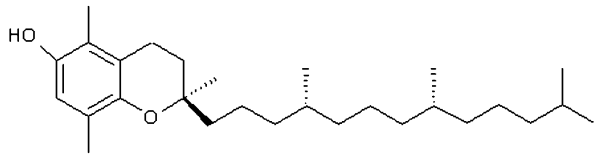

$\beta$-tocopherol

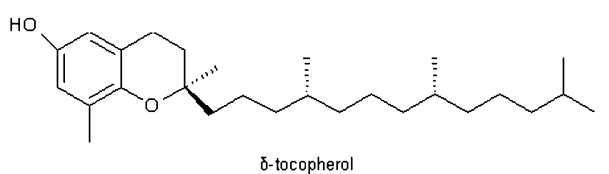<smiles>CC1=C(/C=C/C(C)=C/C=C/C(C)=C/C=C/C=C(C)/C=C/C=C(C)/C=C/C2=C(C)CCCC2(C)C)C(C)(C)CCC1</smiles>

Fig. 2 Chemical structures of bioactive compounds isolated from $F$. betulina 
minimum inhibitory concentration, values in the range from 0.78 to $12.5 \mu \mathrm{g} / \mathrm{ml}$ ) and yeasts including Candida albicans (MIC $6.25 \mu \mathrm{g} / \mathrm{ml}$ ).

Polysaccharides from higher basidiomycota mushrooms have been usually considered to be the major contributors of their bioactivity. However, birch polypore polysaccharides have not yet been sufficiently explored, in terms of either the structure or pharmacological activity. It is known that the Fomitopsis cell wall contains $(1 \rightarrow 3)-\beta$-D-glucans in an amount of ca. 52\% dw (Jelsma and Kreger 1978; Grün 2003). They are built from $\beta$-D-glucopyranose units connected with $(1 \rightarrow 3)$-linkages in the main chain, with $(1 \rightarrow 3)-\beta$-D linked side branches. However, there are no reports about their biological activities. Another polysaccharide isolated from the birch polypore was water-insoluble, alkali-soluble $(1 \rightarrow 3)$ - $\alpha$-D-glucan. Although $\alpha$-glucans are believed to be biologically inactive, its carboxymethylated derivative showed moderate cytotoxic effects in vitro (Wiater et al. 2011).

\section{Miscellaneous applications}

With the knowledge of the mechanisms of action of brown rot decay, there are possibilities of new applications of these fungi in biotechnology. The enzymatic and non-enzymatic apparatus for lignocellulose degradation can be used for bioprocessing of biomass towards fuels and chemicals (Arantes et al. 2012; Giles and Parrow 2011; Ray et al. 2010). Brown rot fungi, including $F$. betulina, were tested for bioleaching of heavy metals $(\mathrm{Cu}, \mathrm{Cr}$, and As) from wood preservatives due to accumulation of metal-complexing oxalic acid (Sierra Alvarez 2007). Production of biomass degrading enzymes, for instance cellulases, hemicellulases, amylases, etc., was also studied (Krupodorova et al. 2014; Valášková and Baldrian 2006a, b).

The cell wall of $F$. betulina can be a source of useful polysaccharides, e.g. water-insoluble, alkali-soluble $\alpha$-glucans (Grün 2003; Jelsma and Kreger 1979). (1 $\rightarrow 3)$ - $\alpha$-D-glucans whose main chain contains $84.6 \%$ of $(1 \rightarrow 3)$-linked $\alpha$-Dglucopyranose in addition to $6 \%$ of $(1 \rightarrow 4)$-linked units were purified and characterized by Wiater et al. (2011). Another polysaccharide, named piptoporane I, was extracted and purified by Olennikov et al. (2012). This $\alpha$-glucan was built from residues of $(1 \rightarrow 3)$ - $\alpha$-D-glucopyranose with occasional branching by single residues of $\beta$-D-glucopyranose at the $\mathrm{C}_{6}$ position $(17.3 \%)$. It has been shown that fungal $(1 \rightarrow 3)-\alpha-D-$ glucans, including that from $F$. betulina, effectively induce the production of microbial $(1 \rightarrow 3)$ - $\alpha$-glucanases (mutanases), i.e. enzymes that have potential in dental caries prevention. $(1 \rightarrow 3),(1 \rightarrow 6)-\alpha-\mathrm{D}-G l u c a n s$ (mutans) synthesized by mutans streptococci are key structural and functional constituents of dental plaque matrix; therefore, they seem to be a good target for enzymatic anti-caries strategy (Pleszczyńska et al. 2015). However, streptococcal glucans are difficult to use as inducers of mutanases because of the low yield and structural variation. Birch polypore $\alpha$-glucan, whose amount in the cell wall of $F$. betulina reaches even 44-53\% dw (Grün 2003), can be used to replace streptococcal glucans (Wiater et al. 2008).

\section{Conclusions and outlook}

The $F$. betulina fungus has been widely used and appreciated in folk medicine, and modern pharmacological studies have confirmed its potential indicating significant antimicrobial, anticancer, anti-inflammatory, and neuroprotective activities. The possibility of successful cultivation thereof in artificial conditions additionally promotes the applicability of the fungus. However, compared with other polypore fungi, the research on $F$. betulina is less developed; for instance, little is known about its lifestyle, including the wood degradation strategy. Moreover, most of the bioactivity studies have been performed using crude extracts; hence, only a few of the effects have been associated with the active substances identified, e.g. antibacterial activities with piptamine or polyporenic acids. With a few exceptions, we still do not know the mechanisms underlying the biological activities. Verification of biological activities in in vivo and clinical studies is also required. The further research could contribute to better exploitation of the $F$. betulina application potential.

\section{Compliance with ethical standards}

Competing interests The authors have no conflict of interest to declare.

Open Access This article is distributed under the terms of the Creative Commons Attribution 4.0 International License (http:// creativecommons.org/licenses/by/4.0/), which permits unrestricted use, distribution, and reproduction in any medium, provided you give appropriate credit to the original author(s) and the source, provide a link to the Creative Commons license, and indicate if changes were made.

\section{References}

Alresly Z, Lindequist U, Lalk M, Porzel A, Arnold N, Wessjohann LA (2016) Bioactive triterpens from the fungus Piptoporus betulinus. Rec Nat Prod 10:103-108

Arantes V, Goodell B (2014) Current understanding of brown-rot fungal biodegradation mechanisms: a review. In: deterioration and protection of sustainable biomaterials. ACS Symp Ser 1158:3-21

Arantes V, Jellison J, Goodell B (2012) Peculiarities of brown-rot fungi and biochemical Fenton reaction with regard to their 
potential as a model for bioprocessing biomass. Appl Microbiol Biotechnol 94:323-338. doi:10.1007/s00253-012-3954-y

Baldrian P, Gabriel J (2002) Intraspecific variability in growth response to cadmium of the wood-rotting fungus Piptoporus betulinus. Mycologia 94:428-436

Baldrian P, Valášková V (2008) Degradation of cellulose by basidiomycetous fungi. FEMS Microbiol Rev 32:501-521. doi:10.1111/j.1574-6976.2008.00106.x

Blumenberg F, Kessler F (1963) Inhibition of the growth of mouse sarcoma S-37 by the birch fungus (Polyporus betulinus). Arzneimittelforschung 13:198-200

Capasso L (1998) 5300 years ago, the Ice man used natural laxatives and antibiotics. Lancet 352(9143): 1864

Cyranka M, Grąz M, Kaczor J et al (2011) Investigation of antiproliferative effect of ether and ethanol extracts of Birch polypore medicinal mushroom, Piptoporus betulinus (Bull.: Fr.) P. Karst. (Higher Basidiomycetes) in vitro grown mycelium. Int J Med Mushrooms 13:525-533. doi:10.1615/IntJMedMushr. v13.i6.40

Dresch P, D’Aguanno MN, Rosam K, Grienke U, Rollinger JM, Peintner U (2015) Fungal strain matters: colony growth and bioactivity of the European medicinal polypores Fomes fomentarius, Fomitopsis pinicola and Piptoporus betulinus. AMB Express 5:4. doi:10.1186/s13568-014-0093-0

Fungorum I (2016) http://www.indexfungorum.org. Accessed 29 Nov 2016

Giles R, Parrow M (2011) Lignocellulosic treatments and applications thereof. United States Patent Application Publication US 20110008384 A1

Grienke U, Zöll M, Peintner U, Rollinger JM (2014) European medicinal polypores-A modern view on traditional uses. J Ethnopharmacol 154:564-583. doi:10.1016/j.jep.2014.04.030

Grishin AA, Lutskii VI, Penzina TA, Dudareva LV, Zorina NV, Polyakova MS, Osipenko SN (2016) Composition of the supercritical $\mathrm{CO}_{2}$ extract of the fungus Piptoporus betulinus. Chem Nat Compd 52:436-440. doi:10.1007/s10600-016-1667-7

Grün CH (2003) Structure and biosynthesis of fungal $\alpha$-glucans. Dissertation, University of Utrecht

Han ML, Cui BK (2015) Morphological characters and molecular data reveal a new species of Fomitopsis (Polyporales) from southern China. Mycoscience 56:168-176. doi:10.1016/j. myc.2014.05.004

Han ML, Chen YY, Shen LL, Song J, Vlasak J, Dai YC, Cui BK (2016) Taxonomy and phylogeny of the Brown-rot Fungi: Fomitopsis and its related genera. Fungal Divers 80:343-373. doi:10.1007/s13225-016-0364-y

Hartikainen ES, Miettinen O, Hatakka A, Kahkonen MA (2016) Decolorization of six synthetic dyes by fungi. Am J Environ Sci 12:77-85. doi:10.3844/ajessp.2016.77.85

Hibbett DS, Donoghue MJ (2001) Analysis of character correlations among wood decay mechanisms, mating systems, and substrate ranges in homobasidiomycetes. Syst Biol 50:215-242

Hibbett DS, Thorn RG (2001) Basidiomycota: homobasidiomycetes. In: McLaughlin DJ, McLaughlin EG, Lemke PA (eds) Systematics and evolution, the Mycota VII Part B. Springer-Verlag, Berlin Heidelberg, pp 121-168

Hori C, Gaskell J, Igarashi K, Samejima M, Hibbett D, Henrissat B, Cullen D (2013) Genomewide analysis of polysaccharides degrading enzymes in 11 white-and brown-rot Polyporales provides insight into mechanisms of wood decay. Mycologia 105:1412-1427. doi:10.3852/13-072

Hybelbauerová S, Sejbal J, Dračínskỳ M, Hahnová A, Koutek B (2008) Chemical constituents of Stereum subtomentosum and two other bitch-associated basidiomycetes: an interspecies comparative study. Chem Biodivers 5:743-750. doi:10.1002/ cbdv.200890070
Jasicka-Misiak I, Lipok J, Swider IA, Kafarski P (2010) Possible fungistatic implications of betulin presence in betulaceae plants and their hymenochaetaceae parasitic fungi. Z Naturforschung C. 65:201-206

Jelsma J, Kreger DR (1978) Observations of the cell-wall compositions of the bracket fungi Laetiporus sulphureus and Piptoporus betulinus. Arch Microbiol 119:249-253

Jelsma J, Kreger DR (1979) Polymorphism in crystalline $(1 \rightarrow 3)-\alpha-D-$ glucan from fungal cell-walls. Carbohydr Res 71:51-64

Ka K-H, Ryu S-R, Lee B-H, Yoon K-H, Bak W-C (2008) Log cultivation of the birch fungus Piptoporus betulinus using Betula davurica. Korean J Mycol 36:98-100

Kaczor J, Klecha IM, Rzeski W, Paduch R, Zdzisińska B, Pożarowski P, Kandefer-Szerszeń M (2004) Extract from Piptoporus betulinus Bull. Fr. suppresses human tumor cell growth. Post Fitoter 2:62-66

Kamo T, Asanoma M, Shibata H, Hirota M (2003) Anti-inflammatory lanostane-type triterpene acids from Piptoporus betulinus. J Nat Prod 66:1104-1106. doi:10.1021/np0300479

Kandefer-Szerszeń M, Kawecki Z (1974) Ether extracts from the fruiting body of Piptoporus betulinus as interference inducers. Acta Microbiol Pol Series A: Microbiologia Generalis 6:197-200

Kandefer-Szerszeń M, Kawecki Z (1979) Water extracts of fungi as source of antiviral substances. Ann UMCS XXXIV 13:163-174

Kandefer-Szerszeń M, Kawecki Z, Guz M (1979) Fungal nucleic acids as interferon inducers. Acta Microbiol Pol Series A: Microbiologia Generalis 28:277-291

Kandefer-Szerszeń M, Kaczor J, Kawecki Z (1981) Fungal extracts as source of antiviral substances. II. Application of the chromatography methods for the isolation of antiviral substances from Piptoporus betulinus (Bull. Ex Fr.). Ann UMCS XXXVI 1:1-20

Karaman M, Mimica-Dukic N, Knezevic P, Svircev Z, Matavuly M (2009) Antibacterial properties of selected lignicolous mushrooms and fungi from Northern Serbia. Int J Med Mushrooms 11:269-279. doi:10.1615/IntJMedMushr.v11.i3.60

Kawagishi H, Hamajima K, Inoue Y (2002) Novel hydroquinone as a matrix metallo-proteinase inhibitor from the mushroom Piptoporus betulinus. Biosci Biotechnol Biochem 66:2748-2750. doi:10.1271/bbb.66.2748

Kawecki Z, Kaczor J, Karpińska T, Sujak I, Kandefer-Szerszeń M (1978) Studies of RNA isolated from Piptoporus betulinus as interferon inducer. Arch Immunol Ther Exp 26:517-522

Keller C, Maillard M, Keller J, Hostettmann K (2002) Screening of European fungi for antibacterial, antifungal, larvicidal, molluscicidal, antioxidant and free-radical scavenging activities and subsequent isolation of bioactive compounds. Pharm Biol 40:518525. doi:10.1076/phbi.40.7.518.14680

Kim KM, Yoon Y-G, Jung HS (2005) Evaluation of the monophyly of Fomitopsis using parsimony and MCMC methods. Mycology 97:812-822. doi:10.3852/mycologia.97.4.812

Krupodorova TA, Barshteyn VY (2015) Alternative substrates for higher mushrooms mycelia cultivation. J Biosci Biotechnol 1(4):339-347

Krupodorova TA, Ivanova T, Barshteyn VY (2014) Screening of extracellular enzymatic activity of macrofungi. J Microbiol Biotechnol Food Sci 3:315-318

Krupodorova TA, Barshteyn VY, Zabeida EF, Pokas EV (2016) Antibacterial activity of macromycetes mycelia and culture liquid. Microbiol. Biotechnol Lett 44:246-253

Lemieszek MK (2008) The estimation of biological activity of water extracts from Piptoporus betulinus and Inonotus obliquus. Dissertation, Maria Curie-Skłodowska University, Lublin, Poland

Lemieszek MK, Langner E, Kaczor J et al (2009) Piptoporus betulinus (Bull.: Fr.) P. Karst. (Aphyllophoromycetideae): in vitro studies. Int J Med Mushrooms 11:351-364. doi:10.1615/IntJMedMushr.v11.i4.20 
Lomberh ML, Solomko EF, Buchalo AS, Kirchhoff B (2002) Studies of medicinal mushrooms in submerged cultures. In: Sanchez et al. (eds) Mushroom biology and mushroom products. The 4th international conference on mushroom breeding and mushroom products. pp 367-377

Lucas EH (1960) Folklore and plant drugs. Papers of the Michigan Academy of Science, Arts, and Letters XLV, 127-136

Meng F, Liu X, Wang Q (2012) Identification of wood decay related genes from Piptoporus betulinus (Bull. Fr.) Karsten using differential display reverse transcription PCR (DDRT-PCR). Biotechnol Biotechnol Equip 26:2961-2965. doi:10.5504/ BBEQ2012.0032

Olennikov DN, Agafonova SV, Rokhin AV, Penzina TA, Borovskii GB (2012) Branched glucan from the fruiting bodies of Piptoporus betulinus (Bull.: Fr) Karst. Appl Biochem Microbiol 48:65-70. doi:10.1134/S0003683812010127

Ortiz-Santana B, Lindner DL, Miettinen O, Justo A, Hibbett DS (2013) A phylogenetic overview of the antrodia clade (Basidiomycota, Polyporales). Mycologia 105:1391-1411. doi:10.3852/13-051

Papp N, Rudolf K, Bencsik T, Czégényi D (2015) Ethnomycological use of Fomes fomentarius (L.) Fr. and Piptoporus betulinus (Bull.) P. Karst. in Transylvania, Romania. Genet Resour Crop Evol 64:101-111. doi:10.1007/s10722-015-0335-2

Peintner U, Pöder R (2000) Ethnomycological remarks on the Iceman's fungi. In: Bortenschlager S, Oeggl K (eds) The Iceman and his natural environment. Springer, Vienna, pp 143-150. doi:10.1007/978-3-7091-6758-8_12

Petre CV, Tanase C (2013) Description of the culture characteristics of some lignicolous basidiomycetes species grown on three synthetic media. J Plant Dev 20:105-114

Pleszczyńska M, Wiater A, Janczarek M, Szczodrak J (2015) $(1 \rightarrow 3)-\alpha$-D-Glucan hydrolases in dental biofilm prevention and control: a review. Int J Biol Macromol 79:761-778. doi:10.1016/j.ijbiomac.2015.05.052

Pleszczyńska M, Wiater A, Siwulski M, Lemieszek MK, Kunaszewska J, Kaczor J, Rzeski W, Janusz G, Szczodrak J (2016) Cultivation and utility of Piptoporus betulinus fruiting bodies as a source of anticancer agents. World J Microbiol Biotechnol 32:151. doi:10.1007/s11274-016-2114-4

Pöder R (2005) The Iceman's fungi: facts and mysteries. Int J Med Mushrooms 7:357-359. doi:10.1615/IntJMedMushrooms. v7.i3.190

Przybył K, Żłobińska-Podejma M (2000) Effects of some bacteria Pseudomonas spp. and Erwinia herbicola on in vitro growth of Piptoporus betulinus. For Pathol 30:321-328

Rapior S, Cavalié S, Andary C, Pélissier Y, Marion C, Bessiére JM (1996) Investigation of some volatile components of seven fresh wild mushrooms (Basidiomycetes). J Essent Oil Res 8:199-201. doi:10.1080/10412905.1996.9700594

Ray MJ, Leak DJ, Spanu PD, Murphy RJ (2010) Brown rot fungal early stage decay mechanism as a biological pretreatment for softwood biomass in biofuel production. Biomass Bioenergy 34:1257-1262. doi:10.1016/j.biombioe.2010.03.015

Reh U, Kraepelin G, Lamprecht I (1986) Use of differential scanning calorimetry of structural analysis of fungally degraded wood. Appl Environ Microbiol 52:1101-1106

Reis FS, Pereira E, Barros L, Sousa MJ, Martins A, Ferreira IC (2011) Biomolecule profiles in inedible wild mushrooms with antioxidant value. Molecules 16:4328-4338. doi:10.3390/ molecules 16064328

Reshetnikov SV, Wasser SP, Tan KK (2001) Higher basidiomycota as source of antitumor and immunostimulating polysaccharides. Int J Med Mushrooms 3:361-394. doi:10.1615/IntJMedMushr.v3.i4.80
Riley R, Salamov AA, Brown DW et al. (2014) Extensive sampling of basidiomycete genomes demonstrates inadequacy of the whiterot/brown-rot paradigm for wood decay fungi. Proc Natl Acad Sci 111:9923-9928. doi:10.1073/pnas.1400592111

Rösecke J, Pietsch M, König WA (2000) Volatile constituents of wood-rotting basidiomycetes. Phytochemistry 54:747-750. doi:10.1016/S0031-9422(00)00138-2

Rutalek R (2002) Ethnomykologie-Eine Übersicht. Österr Z Pilzkd 11:79-94

Schlegel B, Luhmann U, Hartl A, Grafe U (2000) Piptamine, a new antibiotic produced by Piptoporus betulinus Lu 9-1. J Antibiot 53:973-974. doi:10.7164/antibiotics.53.973

Schwarze FWMR (1993) Piptoporus betulinus (Bull.: Fr.) Karsten. Mycologist 7:122-123

Semerdžieva M, Veselský J (1986) Léčivé houby dřive a nyni. Academia Praha, Praha

Shamtsyan M, Konusova V, Maksimova Y, Goloshchev A, Panchenko A, Simbirtsev A, Petrishchev N, Denisova N (2004) Immunostimulating and anti-tumor action of extracts of several mushrooms. J Biotechnol 13:77-83. doi:10.1016/j.jbiotec.2004.04.034

Shang J, Yan S, Wang Q (2013) Degradation mechanism and chemical component changes in Betula platyphylla wood by wood-rot fungi. BioResources 8:6066-6077

Sierra Alvarez R (2007) Fungal bioleaching of metals in preservative-treated wood. Process Biochem 42:798-804. doi:10.1016/j. procbio.2007.01.019

Song Z, Kennedy PG, Liew FJ, Schilling S (2016) Fungal endophytes as priority colonizers initiating wood decomposition. Funct Ecol. doi:10.1111/1365-2435.12735

Stamets PE (2011) Antiviral activity from medicinal mushrooms. United States Patent Application Publication US 20110008384 A1

Stamets PE (2014) Antiviral and antibacterial activity from medicinal mushrooms. United States Patent Application Publication US 201440105928 A2

Suay I, Arenal F, Asensio FJ et al (2000) Screening of basidiomycetes for antimicrobial activities. Antonie Van Leeuwenhoek 78:129 139. doi:10.1023/A:1026552024021

Sułkowska-Ziaja K, Muszyńska B, Motyl P, Pasko P, Ekiert H (2012) Phenolic compounds and antioxidant activity in some species of polyporoid mushrooms from Poland. Int $\mathbf{J}$ Med Mushrooms 14:385-393. doi:10.1615/IntJMedMushr.v14.i4.60

Utzig J, Fertig S (1957) Influence of polyporenic acids on the growth of the bacterium of Brucella. Med Weter 5:268-269

Utzig J, Samborski Z (1957) Effect of triterpenes present in Polyporus betulinus on Sticker's tumors. Med Weter 8:481-484

Valášková V, Baldrian P (2006a) Degradation of cellulose and hemicelluloses by the brown rot fungus Piptoporus betulinus - production of extracellular enzymes and characterization of the major cellulases. Microbiology 152:3613-3622. doi:10.1099/ mic.0.29149-0

Valášková V, Baldrian P (2006b) Estimation of bound and free fractions of lignocellulose-degrading enzymes of wood-rotting fungi Pleurotus ostreatus, Trametes versicolor and Piptoporus betulinus. Res Microbiol 157:119-124. doi:10.1016/j. resmic.2005.06.004

Větrovský T, Baldrian P, Gabriel J (2013) Extracellular enzymes of the white-rot fungus Fomes fomentarius and purification of 1,4- $\alpha$-glucosidase. Appl Biochem Biotechnol 169:100-119. doi:10.1007/s12010-012-9952-9

Vunduk J, Klaus A, Kozarski M, Petrovic P, Zizak Z, Niksic M, Van Griensven LJLD (2015) Did the Iceman know better? screening of the medicinal properties of the birch polypore medicinal mushroom, Piptoporus betulinus (Higher Basidiomycetes). Int J Med Mushrooms 17(12):1113-1125. doi:10.1615/IntJMedMushrooms.v17.i12.10 
Wandokanty F, Utzig J, Kotz J (1954) The action of hydrolysates of Poria obliqua and Polyporus betulinus on malignant neoplastic cells. Med Weter 10:603-605

Wandokanty F, Utzig J, Kotz J (1955) The effect of Poria obliqua and Polyporus betulinus on spontaneous cancer of the dog with respect to breast cancer in dogs. Med Weter 3:148-151

Wangun HVK, Berg A, Hertel W, Nkengfack AE, Hertweck C (2004) Anti-inflammatory and anti-hyaluronate lyase activities of lanostanoids from Piptoporus betulinus. J Antibiot 57:755-758. doi:10.7164/antibiotics.57.755

Wasser SP (2010) Medicinal mushroom science: history, current status, future trends, and unsolved problems. Int J Med Mushrooms 12:1-16. doi:10.1615/IntJMedMushr.v12.i1.10

Wasson RG (1969) Soma: divine mushroom of immortality. Harcourt, Brace \& World, New York

Wasyl A (2006) Evaluation of neurotrophic properties of ethanol and ether extracts from polyporous bracket fungi Piptoporus betulinus (Bull. Ex Fr.) P. Karst in in vitro model. Dissertation, Maria Curie-Skłodowska University, Lublin, Poland

Wiater A, Szczodrak J, Pleszczyńska M (2008) Mutanase induction in Trichoderma harzianum by cell wall of Laetiporus sulphureus and its application for mutan removal from oral biofilms. J Microbiol Biotechnol 18:1335-1341
Wiater A, Paduch R, Pleszczyńska M et al (2011) $\alpha-(1 \rightarrow 3)$-D-Glucans from fruiting bodies of selected macromycetes fungi and the biological activity of their carboxymethylated products. Biotechnol Lett 33:787-795. doi:10.1007/s10529-010-0502-7

Zarzyński P (2009) Correlation between phenolic compounds in wood and its decay by chosen species of saprotrophic and parasitic fungi. For Res Pap 70:113-122. doi:10.2478/v10111-009-0011-4

Žižka Z, Vetrovsky T, Gabriel J (2010) Enhancement of autofluorescence of the brown-rot fungus Piptoporus betulinus by metal ions. Folia Microbiol 55:625-628. doi:10.1007/ s12223-010-0101-y

Zwolińska K (2004) Evaluation of anticancer activity of extracts from birch polypore Piptoporus betulinus (Bull. ex Fr.) P. Karst. Dissertation, Maria Curie-Skłodowska University, Lublin, Poland

Żyła M (2005) Comparison of antitumor activity of extracts from Piptoporus betulinus, Fomes fomentarius and Inonotus obliquus. Dissertation, Maria Curie-Skłodowska University, Lublin, Poland

Żyła M, Rzeski W, Kaczor J, Kandefer-Szerszeń M (2005) Birch tree fungi-a source of substances with therapeutic properties (part II). Med Ogólna 11:187-201 